\title{
Influența limbilor de cultură asupra adaptării numelor străine în limba română în perioada premodernă
}

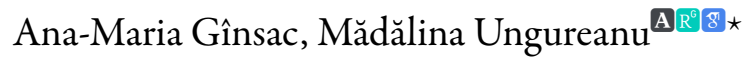 \\ Institutul de Cercetări Interdisciplinare, Departamentul de Științe Socio-Umane, Universitatea „Alexandru Ioan Cuza”, \\ Str. Lascăr Catargi 54, 700107 Iași, România
}

\section{Despre articol}

Istoric:

Primit 27 octombrie 2020

Acceptat 5 noiembrie 2020

Publicat 27 decembrie 2020

Cuvinte-cheie:

contact lingvistic

onomastică

toponimie

traducere

\begin{abstract}
Rezumat
Pornind de la principiul că traducerea este o negociere între două culturi efectuată de un mediator - traducătorul—și că, în consecință, rezultatul final poartă atît urmele mediatorului, cît și pe ale epocii și mediului în care traducerea a fost efectuată, analizăm în acest articol influența pe care o au limbile de cultură asupra traducerii în limba română a numelor proprii străine, în perioada premodernă (sfîrșitul secolului al XVIII-lea și începutul secolului al XIX-lea). Avem în vedere mai multe tipuri de situații. Una ar fi cea în care limba de cultură este și expresia universului de referință al numelor, chiar dacă acestea sînt prezente în texte ale căror originale sînt scrise în altă limbă decît limba de cultură respectivă. În cazul acesta, limba originalului joacă, de fapt, rolul unui intermediar. Alteori, limba de cultură joacă rolul unui model care determină-fără să fie implicat direct în actul de traducere-forma pe care o ia un nume în textulțintă. Influențați de limbile de cultură ale epocii (greacă, latină), traducătorii români din perioada premodernă optează deseori pentru înlocuirea formelor din textele traduse din diferite limbi vernaculare printr-o variantă receptată prin intermediul limbilor de cultură.
\end{abstract}

\section{Preliminarii}

Cînd vine vorba despre traducerea numelor proprii geografice în perioada actuală, Neumark $(1988$, p. 216) recomandă verificarea lor în cel mai recent atlas. Recomandarea DOOM $^{2}$ (p. LII-LIII) este reproducerea întocmai a formelor grafice și fonetice din limbile de origine, ceea ce, însă, poate produce probleme de receptare și recunoaștere la nivelul pronunției. Problemele sînt cu atît mai mari atunci cînd vorbim despre traducerea numelor în perioada premodernă a scrisului românesc (cca 1780-1830). Lipsa normelor de adaptare, asimetriile sistemelor lingvistice aflate în contact (la nivel grafic, fonetic, morfosintactic), o serie de factori socioculturali, strîns legați de situația politică a provinciilor românești, au făcut ca traducătorii să aibă la îndemînă un mare număr de posibilități de transpunere, pe care le-au pus în act în mod nesistematic, rezultînd variații ale aceluiași nume atît de la un traducător la altul, cît și în cadrul aceluiași text.

Traducerea este un act de intermediere între două (sau mai multe) limbi și, de asemenea, între sistemele culturale pe care acestea le exprimă, intermediere pe care o face traducătorul, pe baza unui act de interpretare (Venuti, 1995, p. 17: „Translation is a process by which the chain of signifiers that constitutes the source-language text is replaced by a chain of signifiers in the target language which the translator provides on the strength of an interpretation”). Așadar, textul tradus poartă urmele mediatorului. Dacă în perioada contemporană se poate vorbi despre o tendință spre invizibilitate a traducătorului, astfel încît textul tradus să dea impresia că nu este o traducere, ci un text original (Venuti, 1995, p. 1-2), în perioada mai veche, opțiunile pentru o formă sau alta, pentru o strategie de traducere sau alta purtau în mod evident, printre altele, amprenta traducătorului.

Sandnes (2016, p. 541-550) consideră că schimbările pe care le cunosc numele la contactul dintre două limbi, deci și în traducere, sînt determinate de trei factori: a) caracteristici socio-culturale, b) limbile

^Adrese de corespondență: anamaria.gansac@gmail.com (AMG),madandronic@gmail.com (MU). 
Ana-Maria Gînsac, Mădălina Ungureanu

care intră în contact și c) vorbitorii, asimilabili, în cazul traducerilor, cu traducătorii-mediatori. Cu alte cuvinte, traducerile nu poartă numai amprenta limbilor care intră în contact, ci și pe cea a mediului în care are loc acest proces de intermediere (Zauberga, 2006, p. 150). În ceea ce privește limbile care intră în contact, un rol important îl joacă gradul de prescriptivism lingvistic al limbii-țintă și substratul ideologic care stă la baza acestuia. De exemplu, vorbind despre lituaniana contemporană, Zauberga (2006, p. 144) arată că ea se caracterizează prin conservatorism, purism, iar lingvistica oficială este suspicioasă față de schimbările lingvistice, față de influențele de orice fel, considerînd că lituaniana este pusă în primejdie de prezența unor limbi cu un număr mai mare de vorbitori și cu un prestigiu mai mare, cum sînt engleza și rusa. Această atitudine determină alegerea strategiei de traducere a numelor, orientînd-o către transcriere, nu către transfer. Ne-am referit, astfel, și la un alt factor determinant care ține de limbile ce intră în contact în procesul de traducere: relațiile dintre ele. Prestigiul mai mare al unei limbi-și, deci, al unei culturidetermină strategii de traducere care se apropie într-un grad mai mare de literalism, în sensul unui respect mai mare nu numai față de sensul din limba de origine, ci și față de forma de acolo, o „străinizare” (foreignizing) a textului-țintă („when a culture is accorded prestige, there tend to be many literalist translations from it”, Pym, 2006, p. 10). Extrapolat la numele proprii, acest principiu ar suna astfel: prestigiul mai mare al unei limbi determină strategii și procedee de traducere care au ca rezultat o amprentă puternică a limbii respective asupra formei numelui din limba-țintă.

\section{Factori care determină opțiunile de adaptare a numelor străine în româna premodernă}

La finalul veacului al XVIII-lea și începutul secolului al XIX-lea, sub influența culturală a Iluminismului apusean, în provinciile românești începe un amplu proces de laicizare a culturii scrise și, totodată, de modernizare a limbii române, prin traduceri din diverse limbi occidentale. Această perioadă „de tranziție” între vechea română literară și româna literară modernă (Gheție, 1982, p. 65) a fost numită „epoca premodernă” (Piru, 1970, p. 5). Factorul determinant a fost pluriculturalismul care caracteriza spațiul provinciilor românești în epocă, rezultat al contactului cu marile imperii din vecinătate, Imperiul Habsburgic, Imperiul Rus și, mai ales, Imperiul Otoman (Corbea-Hoișie \& Dima, 2014, p. 8-11; vezi și Ursu \& Ursu, 2004, p. 10-14). În cazul traducerilor pe care le avem în vedere pentru studiul de față, pluriculturalismul se manifestă la mai multe niveluri: a) la nivelul formării traducătorului; b) la nivelul limbilor care intră în contact în procesul de traducere, deci al sistemelor lingvistice și culturale între care se negociază sensul și forma (în cazul numelor proprii); c) la nivelul influențelor predominante în spațiul cotidian al traducătorului. Majoritatea traducerilor din această perioadă vizează originale scrise în limbi occidentale, dar apropriate prin intermediul unei alte limbi, de cele mai multe ori limba greacă (vezi, în acest sens, și tipologia propusă de Dima \& Dima, 2016, p. 12-13). Astfel, dacă traducerea presupune o negociere între două culturi, cu limbile aferente, lucrurile sînt cu atît mai complicate pentru textele despre care vorbim aici („mediated” sau „second-hand translations”, „translations of translations”, după Aixela, 1996, p. 52). Aceasta face ca în ecuație, în traducerile la care ne referim, să fie implicate nu numai două limbi-a textuluisursă și a textului-țintă-, ci mai multe: celelalte limbi cunoscute de traducător sau limbile de cultură folosite pe teritoriul său de proveniență. Aflat în faţa unei secvențe grafice inedite pentru el, cu atît mai mult cu cît numele sînt, de cele mai multe ori, exonime și în limba din care se traduce, traducătorul român o redă nu conform convențiilor ortografice ale limbii din care traduce, ci prin raportare la cele ale unei limbi terțe (cf. „assimilazione indiretta”, Schweickard, 1992, p. 127). Această limbă terță este, de cele mai multe ori, limba de cultură dominantă în regiunea din care provine traducătorul.

Înțelegem aici conceptul de limbă de cultură drept limbă în care se vehiculează conținuturile culturale, nu ca limbă scrisă sau limbă literară:

„O chestiune ce trebuie avută în vedere atunci cînd ne ocupăm de modernizarea limbii române literare este aceea a înrîuririi exercitate în cursul timpului de unele limbi de cultură, dominante într-o epocă sau alta" (ILRLEV, p. 41); 
„alfabetul chirilic românesc este, cu foarte puține deosebiri, alfabetul limbii slavone care a funcționat ca limbă de cultură (a bisericii, a cancelariei domnești etc.) în arealul ortodox dominat de limbile slave sudice sau răsăritene, într-un mod perfect asemănător şi simetric cu rolul jucat de limba latină și de alfabetul latin în țările catolice din apusul, centrul și nordul Europei” (Boerescu, 2014, p. 104).

Pentru perioada de tranziție, rolul limbii de cultură este jucat, în Moldova și Muntenia, de limba greacă. Gáldi (1939, p. 127-128) vorbește despre „bilingvismul” româno-grecesc (neogrecesc) care a caracterizat clasele cultivate. Arvinte (2006, p. 97) nuanțează, arătînd că acest bilingvism caracteriza doar clasa dominantă, „căreia îi aparțineau și cei mai mulți dintre cărturarii vremii”, mai ales că grecii ,au un rol cumpănitor și în viața religioasă și culturală a Țărilor Românești” (Arvinte, 2006, p. 102). În Transilvania, influenței limbii latine, limbă a culturii și administrației, i se adaugă cea a limbii germane, care era și ea limbă a administrației în Imperiul Habsburgic, ceea ce înseamnă că ele erau cunoscute oamenilor educați. Ivănescu (2000, p. 631) arată că, în perioada premodernă, pînă la 1830, limba română literară a fost influențată mai mult de greacă, rusă și germană decît de latină și limbile neolatine: „ea avea un caracter vădit oriental sau germano-oriental, și anume: grecesc, rusesc și turcesc în Principate, german și latino-maghiar peste munți”” Așa se face că unele neologisme de origine romanică, intermediate de aceste limbi, ,au căpătat nu numai un aspect fonetic grec, rusesc sau germano-maghiar, dar și sufixe care nu se găseau în limba de origine și n-ar fi avut rost să apară în românește” (Ivănescu, 2000, p. 638).

În cazul numelor din corpusul nostru $\left(\right.$ RONAME $\left.^{1}\right)$, limbile de cultură (greacă, mai ales, apoi latină, la care se adaugă germana) joacă rolul de intermediar între limba textului-sursă și limba română, impunînd anumite pronunții, oferind soluții pentru interpretarea anumitor grafii sau chiar forme curente în epocă ale unor nume. Din corpusul analizat fac parte texte care au fost traduse din greacă, germană, franceză, italiană și rusă² ${ }^{2}$. In unele cazuri, traducătorii s-au folosit de traduceri intermediare pentru texte scrise de autori occidentali; de exemplu, Cat.rom. este o astfel de traducere: lucrarea originală-o sinteză din autori englezi și germani prin intermediul unor versiuni în limba franceză (Camară, 2017, p. 28)—este scrisă în limba italiană, de aici este tradusă în limba greacă, de unde este tradusă în limba română. Pornind de la studiul din Gînsac et al. (2017), am urmărit două tipuri de situații: cele în care limba greacă este și limba originalului traducerii, pentru a analiza impactul acesteia asupra adaptării formelor în limba română, și cele în care limbile de cultură intermediază negocierea lingvistică, fără a fi implicate efectiv în traducere.

\section{Mărci ale influenței limbii de cultură asupra adaptării numelor străine în limba română}

3.1. În textele cu original grecesc, Cat.rom. și Dom.rom. ${ }^{3}$, date fiind alfabetele diferite, procedeul adoptat pentru adaptarea numelor opace de persoane și de locuri este, desigur, transcrierea. Este reprodusă pronunția reuchliniană, neogrecească, specifică epocii, nu cea clasică, erasmică. Astfel, av este reprodus, în transcriere, prin $\mathbf{a B}$ sau av, $\varepsilon v$ prin $\mathbf{\epsilon v} / \mathbf{\epsilon B} / \mathbf{\epsilon} \phi, \varepsilon \iota \operatorname{prin} \mathbf{n} / \ddot{\mathbf{i}}, \eta$ prin $\mathbf{n}, \nu \tau$ prin $\mathbf{N A}_{\mathbf{A}}(1)$. Această caracteristică se aplică atît numelor din sfera culturii grecești și celor care aveau deja o tradiție în limba română, cît și numelor inedite, pe care bănuim că traducătorii le întîlneau pentru prima dată:

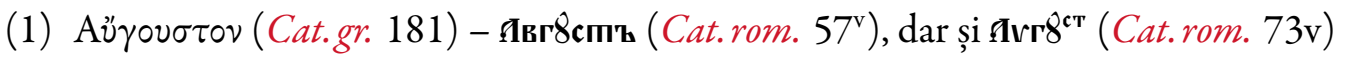

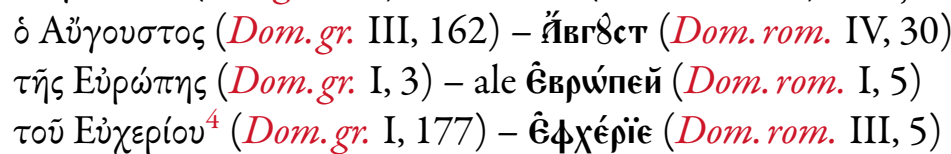

${ }^{1}$ Corpusul conține toate numele străine și formele lor din douăsprezece texte traduse în română în perioada premodernă (1780-1830), precum și corespondentele acestora din textele-surse.

${ }^{2}$ Pentru descrierea textelor și a surselor lor, vezi Camară (2017, p. 15-60).

${ }^{3}$ Ambele sînt traduse de clerici care, prin natura studiilor, erau buni cunoscători de greacă.

${ }^{4}$ Eucherius (antrop.), fiul generalului roman Stilicon Flavius. 


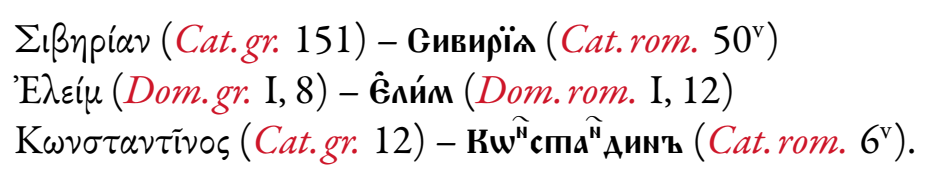

În cazul numelor care se referă la realități din spațiul occidental, acest mod de transfer, printr-o limbă terță, face ca forma românească să fie destul de îndepărtată de cea din limba de origine a numelui, mai ales acolo unde există mai multe intermediare (2), de exemplu:

(2) HAGA (top.): 'Aüav (Cat.gr. 185) - aïa (Cat.rom. 58 v), cf. Haja (Cat.it. 131), cf. și Haag (Rum. rom. 88) - Haag (Rum.germ. 95);

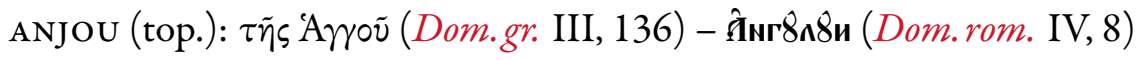

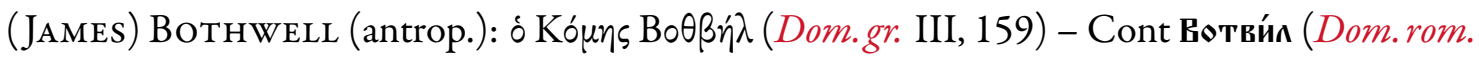
IV, 28).

Alteori, un traducător adoptă transliterarea ca strategie de traducere, ceea ce conduce la îndepărtarea de forma fonetică a numelui din sursă (3a); acest procedeu este combinat în acelaşi text (3b) cu transcrierea pronunției grecești $(\gamma-\mathbf{N \Gamma})$, rezultînd forme hibride $(\gamma-\mathbf{N \Gamma r})$ :

(3a) ANKERSTEIN (antrop.):

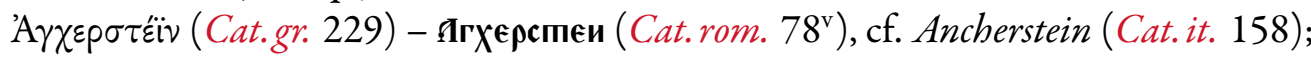

(3b) ARHANGHELSK (top.):

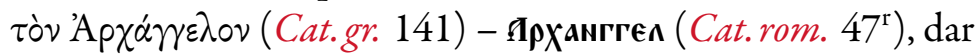

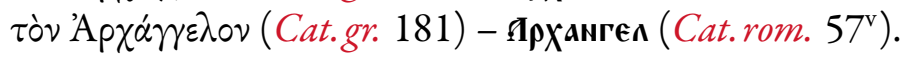

3.2. Influența limbii neogrecești în perioada premodernă a limbii române face ca pronunția specifică ei să fie adoptată inclusiv în texte ale căror surse sînt scrise cu alfabet latin. Interesant în acest sens este tratamentul lui $b$. Acesta este transcris, de regulă, conform pronunției neogrecești /v/, ca в $(v)$, inclusiv în numele care sînt exonime în raport cu limba greacă. În Dom.rom., deși tradus din greacă, situația aceasta este generală (4a). În Cat.rom., în schimb, există cîteva excepții; este vorba despre nume de persoană de origine germană, mai ales cele terminate în -burg sau -berg (4b):

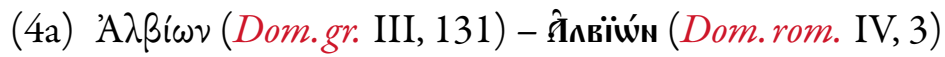

Boviфátios (Dom.gr. II, 185) - Вонифáтї (Dom.rom. III, 16)

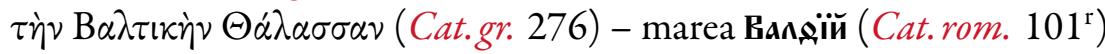

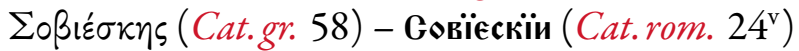

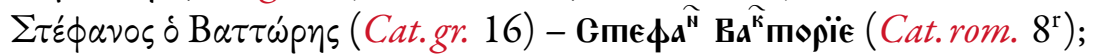

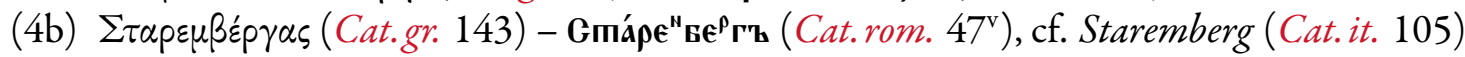

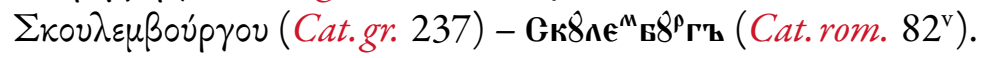

În traducerile cu surse scrise cu alfabet latin, singurul text în care se urmărește cu fidelitate originalul din punctul de vedere al tratamentului lui $b$ este Rum.rom., text apărut la Buda, în afara zonei de influență a limbii grecești. În celelalte texte există excepții. În Flo.rom., excepțiile sînt toponime a căror pronunție tradițională, intrată în limba română pe filieră grecească, era cu /v/: Өи́ви pentru tebani (II, 47), йрáвїa pentru Arabia (II, 100), Иิви́pïa pentru Iberia (II, 102); niciodată nu apare, de pildă, *Tivru (pentru Tibru). În Buf.rom., text asupra căruia și-a lăsat amprenta originalul italian, $b$ este transcris в (de exemplu, Тєвє́, p. 16), cu cîteva excepții: Виза́мтїє, un nume de loc din sfera culturală greacă5, și Врєт́́́iïe, ambele

\footnotetext{
${ }^{5}$ În schimb, deși foarte asemănător formal, toponimul Бизамцónł (Buf.rom. 103, cf. it. Besanzone, fr. Besançon) este ortografiat cu b. De asemenea, apare în Buf.rom. și forma Eрєтагнt, în indice, la final (p. 194), consemnată drept forma nouă pentru Vretanie (cf. Bretagne, Britania, în Buf.fr. 396). Cu atît mai mult, utilizarea lui $v$ pare o alegere conștientă și conservatoare a traducătorului.
} 
receptate prin intermediul limbii grecești. Menționăm că Виза́мтїє apare atît într-un scurt fragment explicativ fără corespondent în textul italian („T, Tarigrádul, care mai dintîi să chiema Vizántie”, p. 14), care reprezintă o adăugire personală a traducătorului la textul tradus (cu atît mai mult, acesta este liber să îl ortografieze în pronunția care îi era familiară), cît și într-un fragment tradus (Buf.rom., p. 14). Cam.rom. transcrie în mod constant pe $b$ prin в; numai în cazul prenumelui exploratorului spaniol Bartolomeu Dias, traducătorul substituie pronunția nouă, caracteristică limbii germane, cu cea tradițional-biblică, grecoslavonă, uzuală în epocă: Bartholomäus (Cam.germ. 152) - Bapsonoméŭ (Cam.rom. 92). Și în Mil.rom. există cîteva nume ortografiate în pronunție neogreacă, deși textul sursă nu o indică; acestea sunt: Vizantia (Indice, XXI), Thévi, Theváida, Livia (Indice, XXII). Traducătorul alternează pronunția de tip neogrecesc cu cea de tip occidental (Thebi Mil.rom. 432, notă marginală); concurența dintre cele două modele este pusă în evidență de o notă a traducătorului: „Pe thevi sau thebani îi părăsesc grecii” (p. 419). Mai multe cazuri apar în Dor.rom. (5), traducere din limba franceză a arhimandritului Gherasim, bun cunoscător de greacă:

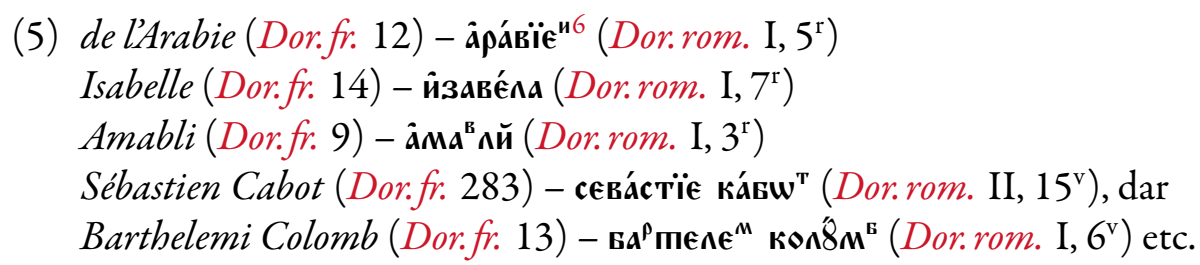

Așadar, tendința epocii este de eliminare a spirantizării și de orientare după uzul latinesc, occidental. Excepțiile se referă, de cele mai multe ori, la realități din sfera culturii grecești sau orientale, nume care deja pătrunseseră în limba română pe filieră greco-slavonă.

3.3. În cazul textelor cu original ortografiat cu alfabet latin, traducătorul folosește pentru echivalarea numelor de persoană cu referenți cunoscuți varianta existentă deja în limbă sau pe cea receptată prin intermediul culturii grecești, după cum arată trăsăturile fonetice: $a u$ - $a v, c h-h, n t-n d$ etc. (6); numele de familie străine sînt preluate de regulă prin transliterare sau prin transcrierea pronunției din sursa tradusă:

(6) Augusto (Buf. it. 372) - Йвг8стьь (Buf.rom. 18)

Augusta (Buf.it. 183) - Йвг8ста (Buf.rom. 89)

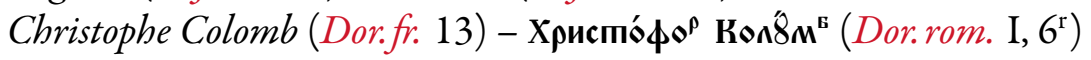

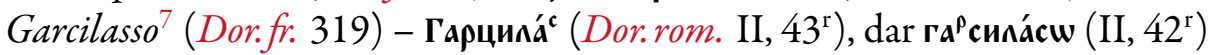

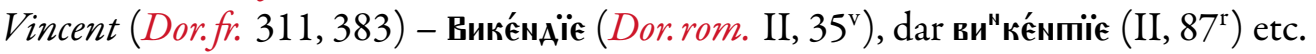

În privința numelor de locuri, deși se întîlnește, probabil, pentru prima dată cu formele unora dintre ele, traducătorul alege să le interpreteze nu după regulile ortografice ale limbii franceze, limba sursei, ci după cele ale limbilor de cultură cunoscute, latina sau greaca: Pichincha ${ }^{8}$ (Dor.fr. 279) este ortografiat пихи́мха

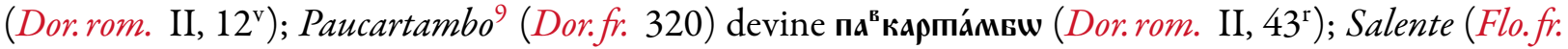
II, 108, 114) este redat prin Gапа́nдї̈и (Flo.rom. II, 80), dar Ganán-ï̈ (II, 85); Quito ${ }^{10}$ (Dor.fr. 280), prin кфímw (Dor.rom. II, 13 ${ }^{\mathrm{r}}$ ) etc.

Confruntarea modelelor-al textului-sursă cu alt model cultural-lingvistic-este reflectată chiar în același text. Pe seama influenței culturii traducătorului trebuie pusă o situație ca cea din Flo. rom., text cu original francez, în care versiunea de origine latină a numelor unor zei sau personaje mitologice celebre este înlocuită cu varianta ei grecească, de exemplu: Jupiter (Flo.fr. I, 29) - 3érc (Flo.rom. I, 20), Hercule (Flo.

\footnotetext{
${ }^{6}$ Am păstrat scrierea originală, fără inițială majusculă, a numelor.

${ }^{7}$ Inca Garcilaso de la Vega, cronicar spaniol (1539-1616).

${ }^{8}$ Numele unei provincii din Ecuador.

${ }^{9}$ Oraș în Peru.

${ }^{10}$ Oraș în Ecuador.
} 


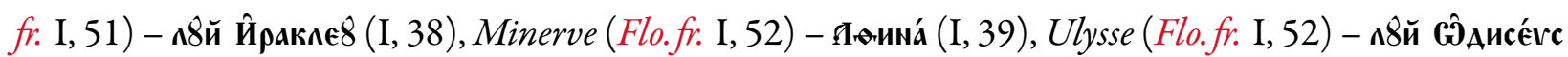
(I, 39), Mars (I, 170) - йрис (I, 134), Venus (II, 64) - १ิфрөди́тїи (II, 47), Vulcain (Flo. fr. II, 217) Йфестос (II, 164) ${ }^{11}$.

În cazul traducerilor cu original german, în transcrierea numelor din sfera culturii antice, traducătorii reproduc pronunția latinească tîrzie, adoptată și în școlile nemțești. Acest lucru este extins și la numele din sfera lumii occidentale, după principiul expus mai sus, în cazul influenței grecești. Întîlnind o secvență grafică inedită, traducătorul Mil.rom. o interpretează conform cunoștințelor lui lingvistice (7a); formele alternează uneori cu cele tradiționale, de exemplu: Țípria - Chiprul. De altfel, traducătorul, foarte bun cunoscător de germană și latină, intervine în textul tradus și indică explicit (7b) faptul că un anumit nume poate avea pronunţii diferite:

(7a) Cicero (Mil.germ. 294) - Ци́цер®м (Mil.rom. 431)

Mycenä (Mil.germ. 152) - Мице́ме (Mil.rom. 204)

Polinyces (Mil.germ. 149) - Полими́цес (Mil.rom. 201)

Cyrus (Mil.germ. 294) - Ци́р8с (Mil.rom. 282)

Cypern (Mil.germ. 297, 235) - Ци́прїа (Mil.rom. 435), dar Ки́пр8п (229);

(7b) Athos (Mil.germ. 202) - „,̂̀óc sau Âsóóc” (Mil.rom. 284)

„des Cäsars” (Mil.germ. 5) - „lui Цеcap sau Kecáp” (Mil.rom. 4)

Cypern (Mil.germ. 282) - „Ки́пр8 sau Ци́пр8п” (Mil.rom. 412)

Hipparchus (Mil.germ. 193) - „Хипа́рх8с sau Înápx” (Mil.rom. 270)

Scyros (Mil.germ. 282) - „Gци́рос sau Gки́рос” (Mil.rom. 412) etc.

În Cam.rom., acest tip de pronunție este extins și la numele din zone geografice îndepărtate (8a), cu excepții $(8 b)$ :

(8a) Guanahani (top.): Guakanahari (Cam.germ. 155) - Квакамаха́ри (Cam.rom. 95)

AGUAdo (antrop.): Aguado (Cam.germ. 167) - Яква́A (Cam.rom. 104);

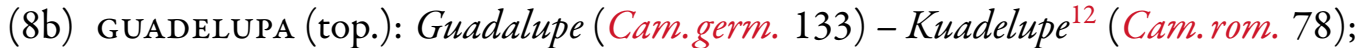
Antigua (top.): Antigua (Cam.germ. 133) - Antiqua (Cam.rom. 78).

3.4. Accentuarea numelor de persoană și de locuri străine nu cunoaște în perioada studiată un tratament stabil în traducere, variind de la un text la altul sau chiar în cadrul aceluiași text. De exemplu, în privinţa accentuării numelor de țări în -(i)ia, Arvinte (2008, p. 99-113) arată că ambele moduri de accentuare, latinesc și grecesc, a numelor în -ia se întîlnesc încă din româna veche, în funcție de orientarea culturală a fiecărui autor, și că în epoca premodernă, în ciuda influenței puternice pe care a exercitat-o cultura greacă în calitate de vehicul cultural în Principatele Române, modelul latinesc este cel predominant. Am urmărit această problemă în textele studiate. Am grupat textele în două categorii, în funcție de tipul de original, pornind de la premisa posibilității ca în textele cu original grecesc să predomine modelul de accentuare grecesc.

În Dom.rom., cele două modele de accentuare, modelul latinesc și modelul grecesc, sînt folosite alternativ, de exemplu: (a) Isspánia (III, 8), Itália (III, 12 et passim), Vréschia (III, 21), Visénsia (III, 21), Dalmáția (III, 38), Lucánia (III, 43), Venéția (III, 51), Bélghia (III, 69), Ungária (III, 69), Sardinia, Córsica (III, 71), Saxónia, Frangónia (III, 77); (b) Galia (III, 8 et passim), Gasconía (III, 12), Liguría (III, 21 et passim), Pavia (III, 21 etc.), Scantinavia (III, 24), Sichelia (III, 25, 29 et passim), Lucania (III, 27), Velghia (III, 29), Campania (III, 35), Sardinia (III, 51), Lombardia (III, 55), Voemia (III, 76); Țárigrad (III, 14), dar Țarigrád (III, 33); la fel, în cazul antroponimelor: Máxim (III, 22, 23), dar Maxim (III, 8); Plachidia (III, 12, 22, 23), dar Plachidia (III, 17, 27) etc. Nu se poate identifica un criteriu care

\footnotetext{
${ }^{11} \mathrm{Cu}$ privire la numele greco-latine în limba română, vezi Costa (1958) și Creția (1958).

${ }^{12}$ Ortografiat în text cu caractere latine.
} 
să determine utilizarea unui mod de accentuare sau a celuilalt într-un anumit context. Pentru numele occidentale, tendința este de utilizare a modelului latinesc, dar aceasta nu este o regulă în cazul tuturor textelor. Dimpotrivă, nici numele de origine orientală nu sunt accentuate numai după modelul grecesc (9b), ci și după cel latinesc (9a):

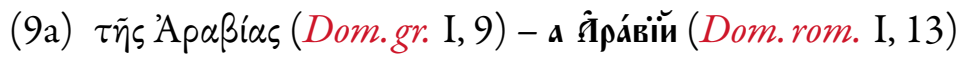

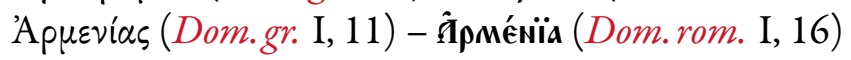

'Aббupía (Dom.gr. I, 9) - Icúpïa (Dom.rom. I, 13)

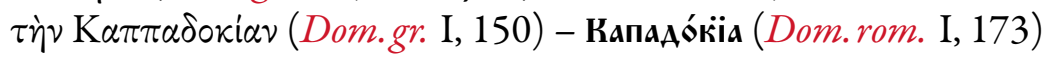

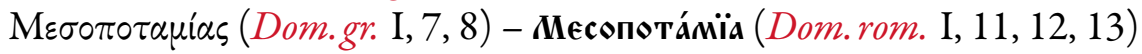

Пepoía (Dom.gr. I, 9) - Пépcïa (Dom.rom. I, 13)

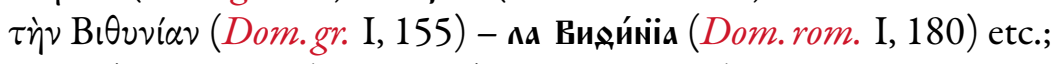

(9b) Eupía (Dom.gr. I, 9) - Gupía (Dom.rom. I, 13)

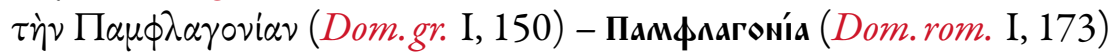

Bıtvía (Dom.gr. I, 154) - Вияикі́a (Dom.rom. I, 179) etc.

În textele cu original scris în alfabet latin, modelul latinesc de accentuare este exclusiv în Buf.rom., Cam. rom., Mil.rom. și Rum.rom., chiar și în cazul numelor din sfera culturii grecești, de exemplu: Novérghie (Buf.rom., Cuprins), Ethiópia (Cam.rom. 10), Itália (Cam.rom. 5), Fríghia (Mil.rom. XXII), Síria (Mil. rom. XXII), Feniția (Mil.rom. XXII), Aústria (Rum.rom. 67), Dalmáția (Rum.rom. 67), Finlándia (Rum.rom. 43), Fránția (Rum.rom. 74). În Flo. rom., traducere efectuată în Moldova ${ }^{13}$, modelele de accentuare coexistă, cu o ușoară preferință pentru cel latinesc: Aráviei (II, 100), Itáliei (II, 18), Pérsia (II, 91), dar Persiei (II, 91) etc.

Textele analizate confirmă concluzia lui Arvinte (2008, p. 110-119) despre preponderența modelului de accentuare latinesc, cu observația că acest fapt nu trebuie pus mai ales pe seama influenței Școlii Ardelene (Arvinte, 2008, p. 118), modelul latinesc fiind predominant și în textele traduse în Moldova.

\section{Concluzii}

Influențaţi de limbile de cultură ale epocii, traducătorii români din perioada premodernă nu optează, adesea, pentru reproducerea prin transcriere a pronunției numelor de locuri și de persoane din textele traduse, ci aleg să le înlocuiască cu o variantă care le este familiară și pe care au receptat-o, aşa cum arată fonetismul, prin intermediul limbilor greacă sau latină. Cînd transcriu nume de locuri și de persoane „exotice” (i.e. îndepărtate de spațiul geografic european sau nemaitraduse, probabil, în română), care, dată fiind noutatea, nu au încă un echivalent românesc, traducătorii nu reproduc, de regulă, pronunția acestora din limba-sursă, ci le transcriu conform pronunției pe care forma lor grafică ar avea-o într-o altă limbă, de obicei greaca. Desigur, în lipsa normelor, formele adaptate din limba textului și cele impuse de prestigiul limbilor de cultură alternează.

\section{Bibliografie}

\section{A. Surse}

Buf.fr. = Géographie universelle, exposée dans les differentes méthodes qui peuvent abréger létude et faciliter l'usage de cette science [...] Par le P. Buffier, de la Compagnie de Jesus. Dizieme édition. Paris, Chez Pierre-François Giffart, 1759.

Buf.it. $=$ [Claude Buffier], Geografia universale del P<adre $>$ Buffier, Edizione prima Romana aumentata, corretta e ridotta in miglior forma, con un nuovo Trattato della Sfera e d'una Dissertazione sopra lorigine eprogresso della Geografia, dal P<adre> Francesco Jacquier, in Roma, a spese di Venanzio Monaldini, mercante di Libri, 1775.

\footnotetext{
${ }^{13}$ Flo. rom. este traducerea lui Alecu Beldiman, publicată la Buda.
} 
Buf.rom. = [Claude Buffier], De obște gheográfie pe limba moldovenească, scoasă de pe Geográfie lui Búfiér după orînduiala care acum mai pre urmă s-au așăzat în Académie de la Parízi, acum întîi tipăită în zilele Prealuminatului și Preaînălțatului Domnului nostru Alexandru Ioan Calimah $\mathrm{V}<$ oie>vod, cu blagosloveniia și cu toată cheltuiala Preaosfințitului Mitropolit a toată Moldáviia, Kirío Kir Iácov, întru a Preosfinției sale Tipográfie, s-au tipărit de ierodiacon Gherásim și de Pável Petrov tipografi), în Sf<ìnta Mitropolie în Iași, avgust 22, 1795.

Cam.germ. = [Joachim Heinrich Campe], Kolumbus oder die Entdekkung von Westindien. Ein angenehmes und nützliches Lesebuch für Kinder und junge Leute, von J.H. Campe, mit allerhochst gnädigst Kayserl. Privilegio, Tübingen, bey Wilh. Heinr. Schramm und Joh. Friedr. Balz., 1782.

Cam.rom. = [Joachim Heinrich Campe], Descoperirea Américii. O carte foarte folositoare, alcătuită de Ioánn Háinrih Cámpe, acum întîiu de un iubitoriu de neamul românesc pre românie tălmăcită și dată afară la lumină, tomul I, cu 4 figuri, cu toată chieltuiala lui Nicóla Nicoláu din Brașov, dată în tipariu la Buda, Crăiasca Tipografie a Universitatei din Péșta, 1816.

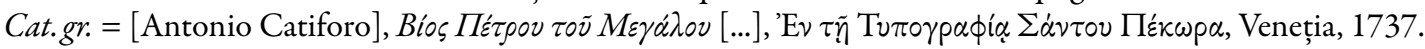

Cat. it. $=$ [Antonio Catiforo], Vita di Pietro il Grande, imperador della Rusia, estratta da varie Memorie pubblicate in Francia e in Olanda, Venezia, Apresso Francesco Pitteri, in Merceria all'Insegna della Fortuna Trionfante, 1736.

Cat.rom. $=$ [Antonio Catiforo], Istoria ruşilor și viața Marelui Petru, monarhul ruşilor, Braşov, 1788 [Ms. 3161, Biblioteca Academiei Române, f.1-186].

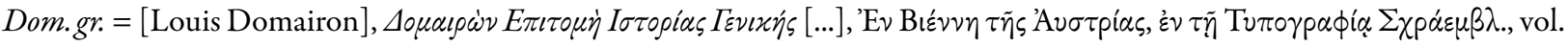
I-III, 1812.

Dom.rom. $=$ [Louis Domairon], Prescurtarea istorii universale, Priveleghiiata Tipográfie din București, București, vol. I-II (1826), vol. III-IV (1827).

Dor.fr. = [André Guillaume Contant d'Orville], Histoire des différents peuples du monde, contenant les cérémonies religieuses et civiles, l'origine des religions, leurs Sectes \& Superstitions, \& les Mours \& Usages de chaque Nation, dédiée à monseigneur le Duc de Vrilliere, ministre et secrétaire d'état par M. Contant Dorville, tome cinquième, à Paris, chez Herissant le Fils Libraire, 1771.

Dor. rom. $=$ [André Guillaume Contant d'Orville], Istoría Americăi, cuprinzind un perilipsis a aflării ei, țerimóniile bisericești și politicești [...], acum întîi tălmăcite în dialectul moldovenesc, prin ostineala smeritului Gherasim, arhimandrit Mitropoliei Iașului, Iași, tomul I (1800), tomul 2 (1795) [în ms. rom. IV-17 BCU-Iași].

Flo.fr. = [Jean-Pierre Claris de Florian], Numa Pompilius, second Roi de Rome, par M. de Florian, Capitaine de dragons et Gentilhomme de S.A.S.Mgr le Duc de Penthievre, de l'Académie de Madrid, à Paris, de l'Imprimerie de Didot l'Aîné, seconde édition, tome I-II, 1786.

Flo. rom. = [Jean-Pierre Claris de Florian], Istoriia lui Numa Pompilie, al doilea craiu al Romii, tălmăcită din limba franțuzească de dumnealui postelnicul Alexándru Beldiman și dată și în tipariu [...] în zilele Prealuminatului și Preaînălțatului nostru Domn al Moldaviei, Mihaíl Grigoríu Suțul Voievod, întru al doilea an a domniei Înălțimii sale, la anul 1820.

Mil.fr. $=$ [Claude François Xavier Millot], Éléments d'histoire générale, première partie: Histoire ancienne, par M. l'Abbé Millot de l'Académie Françoise, \& des Académies de Lyon \& Nancy, tome premier, Nouvelle édition augumentée, à Paris, Chez Durand neveu, 1790.

Mil.germ. $=$ [Claude François Xavier Millot], Des Herrn Abt <Claude> Millot, Mitglieds der Akademie zu Lyon, Universalhistorie alter, mittler und neuer Zeiten, aus dem Französischen, mit den Zusätzen von Wilhelm Ernst Christiani, königlich Dänischen wirklichen Justiz - Rath und ordentlichen Professor der Weltweisheit, Beredtsamkeit und Geschichte, wie auch Bibliothekar der königlichen Universität zu Kiel, Erster Band, Bey Franz Haas Buchhändler, Wien, 1794.

Mil.rom. $=$ [Claude Millot], Istorie universală, ádecă de obște, care cuprinde în sine întîmplările veacurilor vechi, întocmită prin signior Mílot, commembru Académii Frîncești din Lyon, iară acum întîia dată tălmăcită în limba românească, tomul I, în Búda s-au tipărit, în Crăiasca Tipografie Orientalicească a Universitatei Péștii, 1800.

Rum.germ. $=$ [Johann Daniel Friedrich Rumpf], Alexander I, Kaiser von Russland. Ein Regierungs- und Karaktergemälde, von I.D.F. Rumpf, Königl. Preuss. expedir. Secretär bei der Abgaben-Direction in Berlin, bei G. Hayn, mit dem Bildniss des Kaisers, 1814.

Rum.rom. = [Johann Daniel Friedrich Rumpf], Arătarea stăpînirei și a caracterului lui Alexándru I, împăratul a toată Róssia, întocmită prin I.D.F. Rumpf, Crăiescul Praisesc a Direcției din Berlin Secretar-Expedítor și Mărirei Sale celui pre dreptate și moștenitoriu Craiu al Borúsiei Frídrih Vílhelm III închinată, iară acum întîiu pre Românie prefăcută și tipărită la Buda, în Crăiasca Tipografie a Universitatei Ungáriei, 1815.

\section{B. Lucrări de referință}

Aixela, J.-Fr. (1996). Culture Specific Items in Translation, în R. Alvarez, M. Carmen-Africa Vidal (ed.), Translation, Power, Subversion, Multilingual Matters, Clevedon, p. 52-78.

Arvinte, V. (2006). Studii de istorie a limbii române, Editura Universităţii „Alexandru Ioan Cuza” din Iași, Iași.

Arvinte, V. (2008). Român, românesc, România. Studiu filologic, ediția a III-a, Casa Editorială Demiurg, Iași.

Boerescu, P. (2014). Din istoria scrierii românești, Editura Academiei Române, București.

Camară, I. (2017). Catiforo, Viața Marelui Petru (Iaşi, 1788), în Gînsac et al., 2017, p. 27-29. 
Corbea-Hoișie, A. \& Dima, E. (2016). Începutul modernizării culturii române și racordarea la Occident prin traduceri, Editura Universităţii „Alexandru Ioan Cuza” din Iași, Iași.

Costa, T. (1958). Numele proprii latinești în românește, în „Limba română”, VII (4), p. 70-77.

Creția, P. (1958). Numele proprii grecești în românește, în „Limba română”, VII (2), p. 54-59.

Dima, E. \& Dima, G.-E. (2016). Traducătorii români și traducerile laice din secolul al XVIII-lea, Editura Universității „Alexandru Ioan Cuza” din Iași, Iași.

DOOM $^{2}$ = Academia Română, Institutul de Lingvistică „Iorgu Iordan - Al. Rosetti”, DOOM. Dicționarul ortografic, ortoepic și morfologic al limbii române, ediția a II-a, revăzută și adăugită, Editura Univers Enciclopedic, București, 2005.

Gáldi, L. (1939). Les mots d’origine néo-grecque en roumain à l'époque des Phanariotes (Magyar-Görög tanulmányok, 9), Pázmány Péter, Budapest.

Gheție, I. (1982). Introducere în studiul limbii române literare, Editura Științifică și Enciclopedică, București.

Gînsac A.-M. et al. (2017). Practici de traducere a numelor proprii în scrisul românesc premodern (1780-1830), Editura Universității „Alexandru Ioan Cuza” din Iași, Iași.

ILRLEV = Istoria limbii române literare. Epoca veche (1532-1780), Ion Gheție (coord.), Editura Academiei Române, București. Ivănescu, G. (2000). Istoria limbii române, ediția a II-a, Junimea, Iași.

Neumark, P. (1988). A Textbook of Translation, Prentice Hall International, New York - London - Toronto - Sydney - Tokio. Piru, Al. (1970). Istoria literaturii române, II. Epoca premodernă, Editura didactică și pedagogică, București.

Pym, A. (2006). On the Social and the Cultural in Translation Studies, în A. Pym, M. Shlessinger, Z. Jettmarová (eds), Sociocultural Aspects of Translating and Interpreting, John Benjamins Publishing Company, Amsterdam - Philadelphia, p. 1-26, Crossref.

Sandnes, B. (2016). Names and Language Contact, în C. Hough, D. Izdebska (ed.), The Oxford Handbook of Names and Naming, Oxford University Press, Oxford, p. 541-553, Crossref.

Schweickard, W. (1992). Le modalità di integrazione dei nomi propri stranieri in italiano, în „Nouvelle revue d'onomastique”, 19-20, p. 127-134, Crossref.

Ursu, N.-A. \& Ursu, D. (2004). Imprumutul lexical în procesul modernizării limbii române literare, I. Studiu lingvistic și de istorie culturală, Editura Cronica, Iași.

Venuti, L. (1995). The Translator's Invisibility. A History of Translation, Routledge, London - New York.

Zauberga, I. (2006). Translation as a Discursive Import: Changes in the Transfer of Proper Nouns in Latvian, în A. Pym, M. Shlessinger, Z. Jettmarová (eds), Sociocultural Aspects of Translating and Interpreting, John Benjamins Publishing Company, Amsterdam - Philadelphia, p. 143-150, Crossref. 